\title{
Learning from Black Theology
}

\author{
Basil Moore \\ basilm@comstech.com
}

\begin{abstract}
Black Theology had a profound effect on the religious, especially Christian scene in South Africa in the late 1960, 1970s and 1980s. The traditional stance was that clergy should not get involved in politics. What Black Theology in fact enabled clergy to understand, was that the Gospel was not primarily about the forgiveness of sins but about setting the oppressed free. Thus, politics was at the heart of the work of the clergy in South Africa. Black Theology also had a radical understanding of God. While the need for Black Theology may be less critical in post-Apartheid South Africa, there are major lessons to be learned from how it constructed the Gospel message in the then current context of the oppression and exploitation of the oppressed South African blacks. (This article is an edited version of my honorary doctorate presentation at Rhodes University in 2012.)
\end{abstract}

Keywords: Black Theology, politics, oppressed, freedom, radical understanding of God, post-apartheid South Africa, Gospel message

This presentation reflects on Black Theology, over 40 years from its emergence as an overt, self-conscious and radically new theology in South Africa. I choose to do this because I was intimately involved with the emergence of Black Theology in South Africa and secondly because of its link to Saleem Badat's passionate recognition of the part played by black students in the struggle for liberation in his recent history of SASO, the South Africa Students' Organi- 
zation. Here I recount the story of a different group of black students and the ideas that informed their struggle.

Black Theology is now a spent force but nevertheless it has lessons for us all. I offer now my story which I have entitled, Learning from Black Theology.

Black Theology will forever be associated with the University Christian Movement (UCM) which formed in 1967 in opposition to the long established Student Christian Association (SCA).

I remind you that in Apartheid South Africa the SCA was for white English-speaking Protestant students. There was a separate organisation for white Afrikaans-speaking students and also distinct associations for those labelled 'non white' - black, coloured and Indian students. When the World Student Christian Federation demanded an end to this racist structuring, the SCA refused and disaffiliated from the world body. At this time I was Methodist chaplain to Rhodes University and in concert with Fr. Colin Collins, the national catholic Chaplain and Fr. John Davies, the national Anglican chaplain, we proposed a new student Christian body which would be both nonracial and radically ecumenical by including both Catholics and Protestants. We submitted our idea to our parent church bodies in 1966 who agreed to sponsor the new body which we called the University Christian Movement (UCM). Its inaugural conference was held in July 1967 at the Anglican-run teacher training college in Grahamstown. The nuns who formed part of the staff of that college courageously agreed to accommodate both black and white students attending the conference. About 90 students attended. Over the next 2 years 30 branches were established in universities and seminaries and training colleges. The government at this time banned the student wings of the ANC and the PAC, so black students joined up with UCM as virtually the only place they could meet, making it almost overnight a black majority body.

At this time on the other side of the world it also happened that a student Christian body, also called the University Christian Movement had been formed in the USA. They invited our fledgling UCM to send three members to their conference in Cleveland Ohio in December of 1967. I was chosen as one of the three to attend. One of the others was, as we were to discover later, an undercover security branch policeman. The third member, Bob Kgware, was murdered (by driving a bicycle spoke through his heart) by unknown assailants (but presumably security police) very shortly after our return. 
While in America we met black Americans who were deeply involved in the Black Power Movement and who were subjecting the Civil Rights Movement and its political strategies to powerful criticism. Here we were also able to get hold of some of the early writings of the influential American black theologian, James Cone, notably Black Theology and Black Power and later to meet Cone himself. These encounters had a lasting impact on me and I was persuaded of the validity of Cone's theology.

Back in South Africa the second national conference of the UCM was held at Stutterheim in 1968. One of the historically most important events was the holding of a black caucus initiated by Steve Biko. From this came the decision to form a body where black students could meet to discuss issues directly relevant to their personal lives and lived experiences. This led to the formation of the South African Students organisation (SASO) shortly after.

While this piece of historical curiosity locates the birth of Black Theology within the institutional context of the UCM, it doesn't answer the question of how and why it emerged there in 1970 since SASO, the parent body of the Black Consciousness Movement with which Black Theology was indisputably associated in its beginnings had been up and running vigorously since late 1968. The formation and rapid growth of SASO raised difficult questions about the relations between it and the UCM. Many of the founding members of SASO like Steve Biko (also an executive member of UCM) and Barney Pityana were Christians who wanted to maintain their involvement with the UCM. They recognised that SASO was not and could not become a Christian organisation. So SASO, committed as it was to the development of Black Consciousness ideology was recognised as the coordinating agency for black students' politics. What the Christian members demanded of the UCM was the development of a theological counter-point to Black Consciousness which would address the issue of black liberation. The demand became more strident in 1970 as black students became increasingly scornful of UCM's engagement in humanistic 'encounter groups' and the like, which reflected a liberal reconciliation mind-set.

As a trained theologian now under the influence of James Cone I wrote an exploratory study paper called Towards a Black theology in 1970. This paper was distributed to all members, affiliates and the sponsoring churches. The immediate and tangible effect was that the UCM established a Black Theology project and appointed Sabelo Ntwasa as its full-time organiser. Out of this came a sequence of conferences on Black Theology across the country 
during 1971, with the publication at the end of the year of a selection of conference papers. This publication was immediately banned by the South African government. In the following year, however, the collection was published by the London publisher, Christopher Hurst, under the title Black Theology the South African Voice, which, of course, was also banned in South Africa.

Black Theology took its understanding of 'black' from the Black Consciousness Movement, which used 'black' as a positive identifier opposed to the negative term 'non-white'. Thus 'black referred to all the victims of racism collectively (that is, it included 'Coloureds' and 'Indians'). But 'black' had a strong political meaning as well. It was not simply about pigmentation but more importantly an attitude of mind. So 'black' referred specifically to those victims of racism who were engaged personally and directly in the liberation struggle. 'Black', if you like, referred exclusively to black liberation activists. With this understanding of 'black' Black Theology had to grow out of and be part of the liberation struggle.

What was most distinctive about Black Theology was its theological method. In essence this was grounded in the conviction that in a racist society, racism not only structures the experiences of the oppressors and their victims differently, it also makes them interpret things differently. As such the nature and meaning of the Gospel is understood differently when it is approached within the experiential context of white oppressors from what it is when black experiences and aspirations inform the interpretation. Thus whites are likely to see the heart of the Gospel as being about the salvation of the soul. Whereas for blacks the primary message is that Jesus came to set the oppressed free. It is about liberation. Thus Black Theology is about black people interpreting the Gospel in the light of black experiences as well as interpreting black experiences in the light of the Gospel. What was central to black experience in South Africa was their systematic racist oppression, and interpreting the Gospel called for an answer to how the Scriptures address this reality of oppression. The answer of Black Theology was that the Gospel was a message of liberation of the oppressed. This had to be understood as an authentic Christian response to oppression.

It is useful to reflect on some of the core issues addressed by Black Theology as were reported in the banned collection of papers which I had edited and then published as Black Theology, the South African Voice.

One was an attack on authoritarianism in all its social formations inclu- 


\section{Basil Moore}

ding religion. The essence of the argument by Mokgethi Motlabi was that to allow others to rule over us and make decisions for us compromises our dignity and authenticity as human beings. This argument was carried over into an attack on the authoritarian images of God (omnipotent, King, ruler, Lord, etc.). We are supposed to obey the will of these authoritarian figures. Authoritarian images of God were seen as locking human beings into a permanent childhood and legitimising the social manifestations of authoritarianism in both church and state. Throughout the UCM and thus early Black Theology there was a relentless quest to find ways, especially theological ways, of affirming human beings as adults. It was argued by Sabelo Ntwasa that we need to explore relational images of God rather than remain locked in the traditional person images. In scriptures there are, he argued, two sets of images of God. One is a set of 'person' images, like King, Lord, father, etc. the other is a set of relational images of God - that God is love, peace, and justice. So that in Ntwasa's thinking, as he said 'where I see justice at work in the world, there I see God. That act of justice is itself what I mean by God. God is not something extra over and above the real-world manifestations of love and justice'. If we persist in giving priority to the 'person' images we end up with authoritarian ideas about God, such as King, Lord, and others and thus we legitimate authoritarianism in church and state. We also end up subjecting God to the Race Classification Act according to which God is indisputably 'White'.

The second major issue arose from the character of the UCM as a radically ecumenical movement including Protestants and Catholics. Having Protestants and Catholics together at conferences and in local branches raised serious practical questions about how they could worship together. The response of the UCM was to develop occasion-specific liturgies. These liturgies had a number of fairly consistent characteristics. They were modelled on relational images of God and human beings. They used dance and drama extensively. They drew for their music and songs on the protest traditions of Europe, the USA, South African black workers and black townships. There was thus an unmistakable political thrust to these occasions of worship, which carried over into the infant Black Theology movement. In the liturgies and papers of the Black Theology conferences the felt need was to translate into forms of worship the understanding of 'black' as those involved in the liberation struggle. Thus there was experimentation with liturgies which set worship in the context of the black liberation struggle to promote that struggle by celebrating it, by firing the will to resistance, by supporting people in the 
struggle and by exploring resistance strategies. Specifically they used traditional African 'praise songs' to celebrate leaders in the struggle, like Nelson Mandela. During the 1971 Black Theology conferences it was these acts of struggle-based worship which were most consistently broken up by the security police. I know of no copies of those liturgies which survived the police raids.

A third major issue was feminism. Feminist issues had become dominant across most of the white women members among branches on white campuses and in regional seminars. This emergence of feminism led to the emergence of a woman's caucus at the 1968 conference in Stutterheim, out of which grew a national women's project, which focussed on exploring the issue of the oppression of women. This development had two important effects. One effect was the presence of a lively women's project which attracted a significant number of radical women into the UCM, many of whom argued that Christianity had always played a significant role in the marginalisation and oppression of women. The attacks on Christianity as inalienably sexist led many sponsoring churches to have doubts about the Christian character of the UCM and to withdraw sponsorship and funding. This put pressure on the UCM to search for the possibility of a feminist theology, which resulted in the dissemination of my study paper Towards a Theology of Sexual Politics In late 1970. This paper even more urgently attacked the 'Person' and 'Person in Authority' images of God in traditional theology and argued the need for inclusive relational images. This was because if you insist on using 'person' images you will inevitably end up giving God a gender, inevitably a male gender and thus legitimising the subordination of women. Thus strong theological links were forged between this emerging feminist theology and Black Theology. The links, however, went deeper than this.

As is well known, and as already mentioned, the 1968 UCM conference at Stutterheim also saw the emergence of a black caucus out of which SASO was born. This placed black women students in a practical dilemma of whether to participate in the women's or the black caucus. This generated heated debate between the women's and the black caucuses. The women argued that black liberation would be no liberation if it left sexism intact. Those in the black caucus argued that this was divisive and would weaken the black struggle. As the women's and the black caucuses and the Women's and Black Theology projects became permanent features of the UCM, these arguments became ongoing throughout the UCM's life. 
This feminist strand within the UCM and the challenges it posed for black women had significant consequences for the emergent Black Theology movement. All but one of the Black Theology conferences had papers addressing this issue by such significant black woman speakers as Winifred Kgware, mother of the murdered Bob Kgware, and Ellen Kuzwayo. Sadly none of these women would consent to the publication of their insightful papers, which brought together the feminist and black liberation struggles. They refused to consent to the publication of their work because they saw that sexism in the church had ensured that they had no formal training in theology and believed that their insights would be dismissed because of it. However, for as long as Black Theology remained in the context of the UCM, the issue of feminism remained on the theological agenda.

When the UCM disbanded in 1974 it handed the Black Theology Project over to SASO.

In 1992, on a visit to South Africa, I undertook a small research project interviewing over 60 people who had been engaged in the Black Theology movement to gauge its significance for the liberation struggle and for their own work. Transcripts of the recordings were published as an occasional paper by the University of South Australia under the title Lord, help Thou our Outrage: Black Theology Revisited. I quote from only two of them, whose words I think have direct relevance to us today.

I begin with Frank Chikane, then Secretary of the South African Council of Churches. He had this to say,

I see myself as a black theologian. You can't have learned your theology and your practical politics together like I have and not be a black theologian at heart. Black Theology has always provided me with the tools to reflect on and to direct my practical struggles. And these struggles have always been with other black people for liberation. That, for me, is the most fundamental characteristic of Black Theology. The black theologians are political activists who reflect on their praxis. If you theologise without involvement, the people will see through you. The struggle of black people against oppression and for freedom; that is what Black Theology is about.

Frank Chikane again argued that Black Theology is a theology which advances the struggle by empowering people. In his words, 
The yardstick by which I judge any theology and thus Black Theology, is whether it advances the struggle of the people. And it does this by empowering the people; by providing them with the spiritual and emotional resources to engage in the struggle. For me black consciousness and Black Theology was a conversion experience. It unleashed in me energies and commitments I never knew were there. It enabled me to engage in political action as a Christian in a way that I would never have believed possible with my conservative Pentecostal background. It brought me into the struggle.

It can be seen that what Black Theology did at that historical point in time was to enable black clergy and black Christians to engage in the political struggle for liberation as Christians. This as we know Frank Chikane likened to a conversion experience. Traditionally black Christians had seen their faith lying outside the political arena. Black Theology located their faith in the very heart of the struggle for liberation. What Black Theology did was engage black Christian students in the liberation struggle.

Black Theology was intimately associated with the Black Consciousness movement. But even as leading Christians ceased to call themselves black theologians, Mcebisi Xundu could claim that:

Every black Christian who today is directly engaged in the struggle as a Christian is a product of Black Theology. Of course, there were black Christians who did engage in the struggle before Black Theology. They did so, however, without being able to hold their political activism and their Christian commitment together. And they were roundly condemned by their churches for being political activists. Today we act as Christian political activists holding it all together and even our church leaders are out there on the streets with us. I don't think that the young people of today who have not had to live in a South Africa without Black Theology will ever appreciate how draining that schizophrenia was for us. As we moved to engage the system we always had to do battle with our churches who told us this was against the will of God.

It is time to reflect in closing on the timeless and lasting significance of Black Theology and to ask what can be learned from it by a new generation of young intellectuals. Firstly I want to reflect on its significance for the business of 


\section{Basil Moore}

doing theology. As we have seen, Frank Chikane could claim that 'the yardstick by which I judge any theology is whether it advances the struggle of the people. And it does this by empowering people by providing them with the spiritual and emotional resources to engage in the struggle. Even though I no longer see myself as a theologian, I have the temerity to say that I heartily concur with that analysis of what constitutes authentic theology. In today's South Africa, 'race' is no longer the primary social and political cleavage. As Saleem Badat has said in his conclusion to his study of SASO:

During the past 15 years of democracy there have been important economic and social gains. Yet the reality is South Africa continues to be one of the most unequal societies on earth in terms of disparities in wealth, income, opportunities, and living conditions. The cleavages of 'race', class, gender and geography are still all too evident. Hunger, disease, poverty, and unemployment continue to blight our democracy. Millions of citizens are mired in desperate daily routines of survival.

Today's struggle in South Africa is no longer liberation from the systematic structures of racist oppression. The arena has shifted to those who suffer the ravages of poverty. The struggle has to be for social justice and thus a more equal society. For me, this means that authentic theology has to listen to the experiences and aspirations of those suffering human beings and, like the black theologians of 45 years ago, today's theologians have to be engaged with these victims of oppression in their struggle for liberation and give voice to their cries. They have to empower them spiritually and emotionally to engage in their struggle. The authentic theologian is still one engaged in that struggle as a political activist.

Our task as intellectuals is still to engage with the victims of injustice, to analyse their plight, to give voice to their distress and their hopes. But it is not to do this standing aloof from their struggle. It needs to be done from the very heart of that struggle. It is to devise and implement strategies that will restore to people their dignity and humanity. Each of us is called upon to become liberation activists for social justice. This is a tough commission requiring courage, great skill and determination.

\section{Acknowledgement}

This article is an edited version of a paper delivered by Professor Moore on the 
occasion of the conferring of an honorary doctorate on him by Rhodes University on 8 April 2011. It is published here for the first time with the kind permission of Rhodes University. But see also, Moore (2013).

\section{Sources}

Badat, S. 2009. Black Man, You are on Your Own. Johannesburg: Steve Biko Foundation.

Moore, B.S. 1972. Black Theology: The South African Voice. London: Christopher Hurst \& Co. Publishers Ltd.

Moore, B.S. 1993. Lord, help Thou our Outrage: Black Theology Revisited. Adelaide: University of South Australia.

Moore, B.S. 2013. Towards a Black Theology (1971); \& Learning from Black Theology (2011). Adelaide: The Charles Strong Memorial Foundation. Available at:

http://www.charlesstrongtrust.org.au/lectures/Basil_Moore_Papers.pdf

Honorary Doctoral Fellow

Rhodes University basilm@comstech.com 